\title{
Musical theatre and politics
}

\author{
Dennis Altman, Professorial Fellow in Human Security, LaTrobe University Melbourne
}

The musical is in some ways the most significant contribution of the United States to theatre. Musicals have long been a space for considerable political expression, which is often overlooked in the tendency to view them as no more than light popular entertainments.

The most discussed piece of musical theatre in the last few years has been Lin-Manuel Miranda's Hamilton, the story of one of the United States founding fathers told through a range of musical styles including hip-hop. By consciously casting mainly non-white actors the show interrogates the meaning of America in an era of growing political polarisation.

But Washington politics are not unusual in the American musical. There are precursors to Hamilton in Leonard Bernstein's White House Cantata and the 1969 musical 1776, both of which cover some of the same terrain as Hamilton. More interesting is the unstated political agenda of musical theatre, given its enormous popularity: if one thinks of major theatre centres such as Broadway or London's West End the most popular and expensive shows are usually musicals, and film adaptations - think Mamma Mia or Cats-bring these shows to millions of viewers. One Wikipedia estimate has at least ten films based upon stage musicals topping 25 million ticket sales worldwide, led by Phantom of the Opera and The Lion King.

I suspect most of you reading this piece will regard musicals with scorn, or at best as light entertainment, suitable for maiden aunts and office parties. But the musical is a complex genre, bridging opera, pop and rock music: while the demands on the voice are different there are many musicals that cross over between classical and popular traditions, ranging from George Gershwin's Porgy and Bess to The Who's Tommy: The Musical. Music for the American musical Kismet [1953] was based on compositions of the Russian Alexander Borodin.

Even music without words will reflect the politics of its day, whether through music composed to please religious and monarchical authority or music that expresses support for revolutionary and nationalistic movements. Beethoven originally dedicated his Third Symphony to Napoleon, then withdrew the dedication in protest when Napoleon crowned himself Emperor. The choral section of his Ninth Symphony, the Ode to Joy, became a symbol of liberation at the fall of the Berlin Wall.

Much of nineteenth century European music was connected with the rise of nationalisms as certain composers - Grieg [Norway]; Smetana [Czechoslovakia]; Sibelius 
[Finland] - became identified with national aspirations. One of the best examples is Giuseppe Verdi, whose chorus of the Hebrew Slaves in his 1841 opera Nabucco became the unofficial anthem of the Italian Risorgimento. And Richard Wagner's increasing reliance of German mythology provided rich material for the Nazis.

Political themes are most evident in opera because they relate a story, and those stories often revolve around political events. Verdi again: his opera The Masked Ball was originally set in the Swedish court, but censors in Rome and Naples, alarmed at the depiction of the assassination of a king, forced him to change the setting to Boston. Interestingly the slain king, Gustavo III of Sweden, is believed to have been homosexual and some contemporary productions have made this explicit.

Throughout the twentieth century the musical was a form which sometimes allowed politically difficult subjects to be put before a wider audience. This was explicit in the collaborations of Kurt Weill with Bertolt Brecht, most notably their Threepenny Opera [1928]. The very successful collaboration of Richard Rogers and Oscar Hammerstein in South Pacific [1949] spotlighted American racism and was attacked by some southern politicians for espousing intermarriage. Hammerstein had also written lyrics and book for Carmen Jones [1943], which transposed Bizet's opera to an African American setting.

It is not an accident that Hammerstein, like Gershwin before him, was Jewish; there is a whole literature on the formative role of American Jews in creating the musical (Lawson 2013, PBS n.d.) This may explain the apparent leftism of many of the most successful shows, and Jewishness itself is a theme in several well-known musicals. Bock and Harnick's Fiddler on the Roof takes place against the background of a pogrom, while Kander and Ebb's Cabaret evokes the looming shadow of Nazism and Mel Brooks' The Producers features the ersatz musical, Springtime for Hitler .

There are complex lines connecting Weill and Hammerstein to Bernstein and Stephen Sondheim who collaborated on the musical West Side Story [1957] which again took up questions of racial tension, adapting the story of Romeo and Juliet to street gangs in New York. Shakespeare has inspired literally dozens of operas, but also musicals such as Cole Porter's Kiss Me Kate, although I am dubious of the claim that Hamlet inspired The Lion King.

Sondheim would go on to write a string of daring musicals, a couple of which have explicitly political themes: Assassins brings together nine attempted assassinations of American Presidents in a complex web of discontent with the American Dream. His Pacific Overtures revolves around western attempts to open up Japan in the nineteenth century, a far more critical view than the caricatures of Gilbert and Sullivan's Mikado. Even in the conformist 1950s musicals sometimes adopted surprising themes such as union organising in The Pyjama Game.

Hamilton has had the same impact on the Trump era as Hair did in the Johnson years. For those of us who came of age politically during the Vietnam War Hair was an extraordinary revelation; as a New South Wales state politician pronounced when it premiered in Sydney in 1970: "I cannot accept the way Hair lampoons accepted standards 
of morality, and loudly proclaims every known vice, from blasphemy to drug-taking to homosexuality and draft dodging." (as quoted in Altman 2012).

Not all creators of musicals see themselves as doing more than creating entertainment. At some point in the early 1980s the librettist Tim Rice came to Sydney for the performance of his musical Evita, and I was part of a small workshop with the master. After he'd spoken, I asked him what the political implications were of writing a musical about Eva Peron, who had, after all, been the first lady of Argentina between 1946 and her death in 1952. He seemed perplexed by the question, even though the musical uses the character of Che, a sort of Greek chorus, to puncture some of the claims of the Peronistas. Ten years later Rice collaborated with two of the group Abba to write the musical Chess, based on a famous Cold War chess match between an American and a Soviet player.

Nor do audiences necessarily grasp the politics of musicals: Les Mis[erables] is based on Victor Hugo's novel of that name which culminates in the popular uprising of 1832: Hugo intended it as a blow against human inequality but I doubt many of the people who are stirred by its revolutionary song ["Do you hear the People sing"] are inspired to rush out and take to the streets. Nor does the fact that bankers are the villains in Mary Poppins suggest that the film unleashed a major backlash against capitalist exploitation. The creators of Les Mis, Claude-Michel Schoenberg and Alain Boubil also wrote Miss Saigon, based to some extent on Puccini's opera Madam Butterfly, and again with an explicit political message. Their success is a reminder that much of what we lazily assume to be American culture is in fact produced in Europe: maybe Schoenberg's and Boubil's career was inspired by Jacques Morali, who created that apparently totally American phenomenon, the Village People.

Musicals, too, almost always reaffirm very conservative images of sexuality and gender, with the almost obligatory happy heterosexual coupling at the finale. [West Side Story is an exception, but Maria lives, unlike Juliet.] The anarchic attitude to sex of The Rocky Horror Show has barely re-emerged since that show premiered in 1973, and while there have been several homosexual themed musicals they tend to reinforce stereotypes both of homosexuality and conventional marriage, as in La Cage aux Folles, which produced the near iconic song I Am What I Am.

Trans* characters are common in musicals - think Priscilla - but they usually end up reinforcing traditional concepts of gender: the apparently daring Kinky Boots has a conventionally happy heterosexual ending. In The boy from $\mathrm{Oz}$ the singer, Peter Allen, struggles to comes out before dying of AIDS at the end. It's one of a number of AIDSthemed musicals, notably Rent and Book of Mormon.

But even where musical end with death they almost always end in celebration: audiences may be moved to tears, but they leave the theatre with a sense that, as Pangloss sings in Bernstein's Candide, this is "the best of all possible worlds". Even musicals produced in the Soviet Union under Stalin followed this imperative; as one commentator wrote: "Despite the ideological message, these musicals were entertaining because they 
lifted the spirits of ordinary citizens and provided a utopian fantasy, an illusion of happiness" (Patel 2018).

\section{References}

Altman, D. (2012). Homosexual: Oppression and Liberation. Revised edition. Brisbane: University of Queensland Press, p. 176.

Lawson, M. (2013). How Jewish artists built Broadway. Guardian. Available at: https://www.theguardian.com/stage/2013/nov/20/how-jewish-artists-builtbroadway-musical [Accessed 01.05.20]

Patel, N. (2018). 5 Soviet musicals that stole Hollywood's limelight. Russia Beyond. Available at: https://www.rbth.com/arts/328920-soviet-musicals-movies PBS (n.s.). Preview. Broadway Musicals: A Jewish Legacy. PBS. Available at: http://www.pbs.org/wnet/gperf/broadway-musicals-a-jewish-legacy-about-thefilm/1476/ [Accessed 01.05.2020]. 